\title{
Public Relations Strategies and Tourism Development in Nigeria
}

\author{
Onyeokoro, Sunday Chizobam ${ }^{1} \&$ Esi-Ubani Chidiadi Obinna ${ }^{1}$ \\ ${ }^{1}$ Department of Marketing, Abia State University, Uturu, Nigeria \\ Correspondence: Onyeokoro, Sunday Chizobam, Department of Marketing, Abia State University, Uturu, Nigeria.
}

Received: November 16, 2018; Accepted: December 3, 2018; Published: December 10, 2018

\begin{abstract}
Non-application of public relations strategies to manage tourism in Nigeria has resulted in the degradation of reputable tourist sites that were once popular. The main objective of the study was to examine the role of public relations strategies on the development of tourism in Nigeria. The survey research design was adopted. Multi-stage sampling technique was used and the sample size was 281. Copies of the questionnaire were administered on the respondents to obtain primary data. Secondary sources of information were obtained from journals, magazines, textbooks, and newspapers. Data obtained were analyzed using multiple regression models in the statistical package for social sciences (SPSS). Findings of the study indicate that documentaries and film shows have a significant relationship with tourism development, awards and ceremonies have a significant relationship with tourism development and also facility visits and sponsorship of discussion groups have a significant relationship with tourism development. The study concluded that public relations strategies are viable techniques and lubricants that are very essential to the revitalization of the tourism industry in Nigeria. The study, therefore, recommended that government at all levels should plan and develop a tourism philosophy which will form the foundation for Nigerian tourism practice that will guide the nation on the type of tourism that is consistent with our national values, aspirations, and ideologies. Destination management organizations should improve and intensify efforts on effective and efficient use of documentaries and film shows, awards and ceremonies as well as facility visits and sponsorship of discussion groups to accurately position the sector as a veritable economic catalyst that can be used to stimulate investment for economic growth and development in Nigeria.
\end{abstract}

Keywords: public relations, tourism development

\section{Introduction}

The tourism sector is one of the veritable economic catalysts that is use to stimulate investment for economic growth and development in both advanced and developing economies globally. Essentially, the advantages associated with tourism can create and motivate a platform for the nation's Destination Management Organizations (DMOs) to host and sponsor major national and international events that can showcase and promote Nigeria's rich cultural heritages and other valuable tourist products to both domestic and international communities. This will stimulate increase tourists traffic and patronage of attractions in the country resulting in huge revenue generation and investments as well as other supporting businesses in the economy. Most importantly, tourism can result in economic diversification and drastic reduction of the nation's dependence on oil.

Meanwhile, tourism promotes cultural exchanges and international cooperation as well as contributes significantly to economic growth of many countries. The World Travel and Tourism Commission (WTTC) report indicates that in 2014, tourism made immense direct contribution to Gross Domestic Product (GDP) of nations; $\$ 457.9 \mathrm{~b}$ for United States of America, \$263b for China, $\$ 112.4 \mathrm{~b}$ for Germany and $\$ 1.56 \mathrm{~m}$ for Nigeria. Contribution to employment creation; 53M for United States, 23M for China, 28.4M for Germany and 883,500 thousand for Nigeria. Research reveals that 100 million Chinese tourists spent an estimate of \$164b in 2014 (National Bureau of statistics, 2015, Punch editorial 2016).

Bhatia (2006) asserts that development of tourism involves interaction with the residents and the external world, creating a strong desire and opportunity for people to visit and appreciate cultural, natural and artificial places of wonder. Ebitu (2012), Uchechukwu (2012) emphasize that tourism development equally involves development of rich content messages, from credible sources through appropriate media selection that have a wider reach to seek patronage from outbound and inbound tourists.

Public relations strategies in this direction are catalysts that can bring favourable balance of actions in the sector. Nwodu (2007) refers to public relations strategies as the different means, approaches and methods of planning the public relations activities of the organization in order to achieve the desired objectives. Public relation strategies 
are action oriented arsenals to lead and guide destination management organizations towards attainment of the desired image and results. Fill (2009), Chukwu (2016) report that public relations strategies generate high levels of trust and confidence that single out public relations as an important technique use to reduce perceived risk. Thus, destination management personnel can employ public relations strategies to assist the development, improvement and revival of tourism activities and attractions in Nigeria.

\subsection{Statement of the Problem}

Tourism is all about public relations and public relations is one of the primary functions of tourism agencies' personnel (Bhatia, 2006). Yet there is no significant and remarkable effort to apply public relations strategies in the promotion, management and administration of tourism by relevant tourism agencies in Nigeria. This has constituted a major setback or gap that Nigeria previously known for renowned major tourism sites ranch resort and other popular sites have depleted in value. Dilapidated social infrastructure like airports and airlines, road networks among others have affected movement of tourists while reputable traditional institutions have lost value. The problem of preservation and maintenance is fundamental because notable destinations known for their peculiar characteristics and beauty like National Art Theater in Lagos and other popular historical heritage sites have been reduced to nothing while the extinction of Nigerian peculiar wildlife is vanishing rapidly. Despite the impressive impact of world tourism, the paucity of reliable data and information available on tourism assets remain a standard setback that is undoing the development of tourism in the country. Thus, the under-performance of Nigerian tourism sector cannot be unconnected with overdue negligence and particularly the inapplicability of public relations strategies to communicate intelligently to the target market on the rich tourism potentials that abound in Nigeria (Ogunnubi, 2017). It is these identified gaps that have motivated the researcher's interest in this study.

\subsection{Objectives of the Study}

The main objective of the study is to explore the role of public relations strategies on the development of tourism in Nigeria. The specific objectives include, to;

1. Determine the role of documentaries and film shows on effective development of tourism in Nigeria.

2. Examine the role of awards and ceremonies on tourism development in Nigeria.

3. Examine the effect of facility visits and sponsorship of discussion groups on tourism development in Nigeria.

\subsection{Research Hypotheses}

The following null hypotheses were formulated to guide the study;

Ho1: Documentaries and film shows have no significant effect on the development of tourism in Nigeria.

$\mathbf{H}_{\mathbf{0} 2}$ : Awards and ceremonies have no significant effect on development of tourism in Nigeria.

Ho3: Facility visits and sponsorship of discussion groups have no significant effect on the development of tourism in Nigeria.

\subsection{Scope of the Study}

The study centered on public relations strategies that are pivotal to the development of tourism in Nigeria. Hence, the study covers as much as possible public relations strategies, like documentaries and film shows, awards and ceremonies and facility visits and sponsorship of discussion groups that will stimulate advancement of tourism in Nigeria. The unit of analysis is the identified tourism management organizations in Nigeria that are charged with the responsibility of tourism development.

\section{Review of Related Literature}

\subsection{Concept of Public Relations}

There are many definitions of public relations but for the purpose of this study, definitions related to the study were adopted. First, public relations are aspect of management science that is essential to the growth and development of tourism business, other business and non business sectors of the economy. Modern public relations function as a catalyst that engineers the development of tourism as an environmental social programme. By means of definition, one of the most outstanding definitions is the Mexican statement of 1978 which refers to public relations as the art and science of analyzing trends, predicting their consequences, counseling organization leaders and implementing planned programmes of action which will serve both the organization and the public interest (Benson-Eluwa, 1999). Public relations is the systematized function that evaluates public attitudes and behaviour, harmonizes the goals, policies and procedure of an individual or organization with the public interest and executes a programme of action to earn public understanding, acceptance and supportive behaviour (Center, Jackson, Smith 
\& Stanberry, 2008). Public relations could be referred to as a process by which organizations establish positive relationship that leads to positive behaviour (Neliaku, 2011).

Public relations can fine tune and forge tourism relationship with distinct and relevant stakeholders who are capable to build and sustain strong socio-economic bridges that will propel tourism understanding and initiative to bring about positive changes in the standard of living of the people.

\subsection{Conceptual Framework}

The conceptual framework discussed the identified variables that guide the study.

Documentaries and film shows and tourism development: This is a film, a radio or television programme that gives facts about an event or idea. It also has to do with documentation of a fact or programme for future purposes. Documentary gives records of or report on fact especially by using pictures or recordings of people or the event concerned. Film show has to do with a series of moving pictures recorded with sound that tells a story, shown on television or at the cinema or movie theater. It shows the moving pictures of real event and also serves as evidence for future purposes. Hence, tourism organizations that do not consider documentaries and film shows as important are heading to imminent failure and collapse. Therefore, documentaries and film shows are essential to the success of any tourism organization (Wood 2007). These will direct the attention of destinations management on tourists and help the organizations to determine what product(s) to supply that can satisfy the tourists. It is a mechanism that if put in proper perspective will enhance effective analysis of tourism trends, aimed at identifying the opportunities and problems.

Awards and ceremonies and tourism development: Ceremonies are planned public or social occasion, often important, interesting and memorable. Ceremony can also be a public or religious occasion that includes a series of formal or traditional actions, awards, wedding or marriage. It is usually a joyous occasion and indeed, a celebration. Once in a while, somebody has to call on relations, friends, well wishers, colleagues and even the public to come together for a social function. Ceremonies are therefore important public relations package (Okoli 2007). Destination management organizations can also organize awards for something that somebody has done. Awards can therefore build a strong and good will image to the tourism organizations. The award presentation is another opportunity to sink in a public relations campaign message of the tourism organization. The essence of all these is to draw public attention on the rich cultural heritage of the tourism organization.

Facility visits and sponsorship of discussion groups and tourism development: This is done to maintain contacts with professional bodies, women societies, youth clubs etc. The tourism organization can invite and sponsor relevant institutions for an excursion in order to have a firsthand look and experience about the natural places of wonder. Sponsorship of discussion groups by the destination management organization is designed to draw the attention of those involved (tourists) on the tourism products. Therefore, tourism organizations that desired to develop can achieve this by sponsoring relevant bodies like student groups, clubs, companies, religious groups etc for a facility visit. This will create a goodwill image about the tourism organization and its publics. The tourism sector needs tourists facility visit to aggressively put the information of the sacred tourism prospects right through sponsorship.

\subsection{Theoretical Framework}

The following theories were considered relevant to the study:

Public Relations Transfer Model: This model was propounded by Jefkins (2005). The theory demonstrates and explains the catalytic function that public relations can play in converting worst negative situations to favouralble situations that can benefit any system.

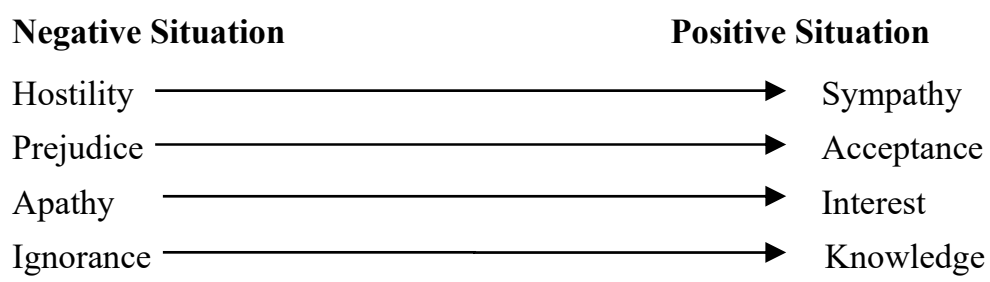

\section{Public relations transfer model diagram}

Source: Jefkins, F. (2005). Public relations, Harlow: McGraw Educational.

This theory explains hostility to mean the existence of problems in an organization, the nature and the reason of the problems and on the other hand sympathy is the task that is most sorted and used to overcome this problem. Prejudice may be as a result of educational, cultural, social, religious, class influences and diplomatic 
misunderstanding. It is an established position that most publics of an organization hold strongly old ways of doing things. Apathy means loss of interest in issues and could be as a result of selfishness, lack of foresight, poor creativity and imagination. The truth about successful public relations information is that it must be interesting and of high value to motivate public. Ignorance is a common pitfall especially in the current dynamic and technologically advanced business world with customers taste changing continuously. The application of the hostility in the model subscribes that most western tourists are hostile and hate to visit Nigeria for various reasons. Prejudice exists in many different forms, like negative western media reportage that Nigeria is underdeveloped and primitive. Ignorance has traditionally deprived many people of the knowledge about attractive tourists products in Nigeria.

Source Credibility Theory: The theory was propounded by Hovland, Janis and Kelly (1996). The source credibility theory states that people are more likely to be persuaded when the source of a presented message is credible, reliable, reputable and widely acceptable. The high point of the theory in the study is that tourists tend to believe seasoned and reputable travel writers, editors and travel journalists including personalities from their home countries. Again, tourists believe strongly the stories written by travel writers who have visited beautiful destinations, witness fantastic festivals among other colourful events in such countries.

\subsection{Empirical Review}

Empirical studies available on public relations and tourism development are relatively rare. Deboski (2013) carried out a study on assessment of marketing communication as a tool of building tourism destination competitiveness. The result of the study was that word of mouth communication was a very effective form of tourism promotion. The study recommended that tourism organization should consider it necessary to nurture tourists' satisfaction as to stimulate expression of positive opinions about destinations. A desk research was conducted by Bogan (2016) on communication and promotion policy in tourism marketing. The study stated that promotion components are very important because they express a destination image at all levels but promotion mix hardly focus on creating new tourist products. The study recommended that promotion must always be combined with the quality of products offered in order to ensure the development of tourism in any tourist destination.

\section{Research Methods}

This study adopted the survey approach. The population of the study comprised staff of identified Destination Management Organizations (DMOs) in Nigeria that are charged with the responsibility of tourism development. The researcher sought from the Tourism Department, Federal Ministry of Information and Culture, the staff strength statistics of the six zonal offices of Nigeria Tourism Development Corporation (NTDC). The search revealed a population figure of 949 . The Taro Yeman formula was applied to arrive at a sample size of 281.

\subsection{Sampling Procedure}

The study adopted multi-stage Sampling technique. Based on the population of the six zonal Offices of Nigerian Tourism Development Corporation (NTDC) and Federal Ministry of Information and culture, Abuja, Tourism Department (FMI \& C(TD), the proportions were calculated as follows:

\begin{tabular}{llll}
\hline S/n & $\begin{array}{l}\text { Zonal offices } \\
\text { \& FMI \& C (TD) }\end{array}$ & Stratified multi-stage sample & Sample size \\
\hline 1. & NTDC S/South & 142 & \\
2. & NTDC S/East & 161 & 42 \\
3. & NTDC S/West & 126 & 48 \\
4. & NTDC N/West & 123 & 37 \\
5. & NTDC N/East & 148 & 36 \\
6. & NTDC N/Central & 173 & 44 \\
7. & FMI \& C(TD) & 76 & 51 \\
& Total & $\mathbf{9 4 9}$ & 23 \\
\hline
\end{tabular}

\subsection{Instrument of the Study}

The instrument of this study was the questionnaire. The questions were based on the variables of the study. Copies of questionnaire were administered on the respondents by the researchers and with the help of the research assistants in these zones and also waited patiently to receive the completed copies of questionnaire.

\section{Results}

Out of the 281 copies of questionnaire that were distributed across the six zonal offices of NTDC and FMI \& C(TD), only 252 were returned and found useable. This represents $90 \%$ response rate. The following are the presentation of results and data analysis. 
Table 1. Gender distribution of respondents

\begin{tabular}{lll}
\hline Options & Frequency & Percentage\% \\
\hline Male & 140 & 55.6 \\
Female & 112 & 44.4 \\
Total & $\mathbf{2 5 2}$ & $\mathbf{1 0 0}$ \\
\hline
\end{tabular}

Source: Field Survey, 2017

Table 1 above shows that out of 252 respondents surveyed, $140(55.6 \%)$ were males while $112(44.4 \%)$ of the respondents were females.

Table 2. Age distribution of respondents

\begin{tabular}{lll}
\hline Options & Frequency & Percentage\% \\
\hline $20-30$ & 66 & 26.2 \\
$31-40$ & 131 & 52.0 \\
41 and above & 55 & 21.8 \\
Total & $\mathbf{2 5 2}$ & $\mathbf{1 0 0}$ \\
\hline
\end{tabular}

Source: Field Survey, 2017

Table 2 above reveals that out of the 252 respondents surveyed, 66 or 26.2 percent of the respondents were between the age bracket of 20-30 years, 131 or 52 percent of the respondents were the range of 31-40 years while 55 or 21.8 percent were between 41 years and above.

Table 3. Marital status of respondents

Source: Field Survey, 2017

\begin{tabular}{lll}
\hline Options & Frequency & Percentage\% \\
\hline Married & 136 & 54.0 \\
Single & 116 & 46.0 \\
Total & $\mathbf{2 5 2}$ & $\mathbf{1 0 0}$ \\
\hline
\end{tabular}

Table 3 above shows that out of 252 respondents surveyed, 136 or 54 percent were married while 116 or 46 percent were single.

Table 4. Academic qualification of respondents

\begin{tabular}{lll}
\hline Options & Frequency & Percentage\% \\
\hline SSCE & 31 & 12.3 \\
ND/NCE & 78 & 31.0 \\
B.SC/HND & 104 & 41.2 \\
M.SC/MBA and above & 39 & 15.5 \\
Total & $\mathbf{2 5 2}$ & $\mathbf{1 0 0}$ \\
\hline
\end{tabular}

Source: Field Survey, 2017

Table 4 above shows that out of 252 respondents surveyed, 31 or 12.3 percent of the respondents were senior secondary school certificate holders, 78 or 31 percent were National Diploma or National Certificate of Education holders, 104 or 41.2 percent had B.Sc/HND certificates while 39 or 15.5 percent of the respondents had M.Sc/MBA and above. 
Table 5. Respondents responses on organization having public relations department

\begin{tabular}{lll}
\hline Options & Frequency & Percentage\% \\
\hline Yes & 59 & 23.4 \\
No & 193 & 76.6 \\
Total & $\mathbf{2 5 2}$ & $\mathbf{1 0 0}$ \\
\hline
\end{tabular}

Source: Field Survey, 2017

Table 5 above shows that out of 252 respondents surveyed, 59 or $23.4 \%$ percent said yes while 193 or $76.6 \%$ percent responded no.

Table 6. Respondents' responses on effect of documentaries and film shows on the development of tourism in Nigeria

Source: Field Survey, 2017

\begin{tabular}{lll}
\hline Options & Frequency & Percentage\% \\
\hline Strongly agree & 120 & 47.6 \\
Agree & 84 & 33.3 \\
Undecided & 17 & 6.7 \\
Disagree & 21 & 8.3 \\
Strongly disagree & 10 & 4.0 \\
Total & $\mathbf{2 5 2}$ & $\mathbf{1 0 0}$ \\
\hline
\end{tabular}

Table 6 above reveals that out of 252 respondents surveyed, 120 or 47.6 percent of the respondents strongly agree that documentaries and film shows effectively affect the development of tourism in Nigeria, 84 or 33.3 percent agree, 17 or 6.7 percent were undecided, 21 or 8.3 percent disagree while 10 or 4 percent of the respondents strongly disagree that documentaries and film shows effectively affect the development of tourism in Nigeria.

Table 7. Respondents' responses on the effect of awards and ceremonies on the development of tourism in Nigeria

Source: Field Survey, 2017

\begin{tabular}{lll}
\hline Options & Frequency & Percentage\% \\
\hline Strongly agree & 106 & 42.1 \\
Agree & 88 & 34.9 \\
Undecided & 26 & 10.3 \\
Disagree & 23 & 9.1 \\
Strongly disagree & 9 & 3.6 \\
Total & $\mathbf{2 5 2}$ & $\mathbf{1 0 0}$ \\
\hline
\end{tabular}

Table 7 shows that out of 252 respondents surveyed, 106 or 42.1 percent strongly agree that awards and ceremonies affect the development of tourism in Nigeria, 88 or 34.9 percent agree, 26 or 10.3 percent undecided, 23 or 9.1 percent disagree while 9 or 3.6 percent of the respondents strongly disagree that awards and ceremonies affect the development of tourism in Nigeria.

Table 8. Respondents' responses on the effect of facility visits and sponsorship of discussion groups on the development of tourism in Nigeria

\begin{tabular}{lll}
\hline Options & Frequency & Percentage\% \\
\hline Strongly agree & 116 & 46.0 \\
Agree & 85 & 33.7 \\
Undecided & 19 & 7.5 \\
Disagree & 22 & 8.8 \\
Strongly disagree & 10 & 4 \\
Total & $\mathbf{2 5 2}$ & $\mathbf{1 0 0}$ \\
\hline
\end{tabular}

Source: Field Survey, 2017 
Table 8 above reveals that out of 252 respondents surveyed, 116 or 46.0 percent strongly agree that facility visits and sponsorship of discussion groups affect the development of tourism in Nigeria, 85 or 33.7 percent agree, 19 or 7.5 percent undecided, 22 or 8.8 percent disagree while 10 or 4 percent strongly disagree that facility visits and sponsorship of discussion groups affect the development of tourism in Nigeria.

Table 9. Tourism development is influenced by marketing and public relations strategies.

Source: Field Survey, 2017

\begin{tabular}{lll}
\hline Options & Frequency & Percentage\% \\
\hline Strongly agree & 99 & 39.3 \\
Agree & 93 & 36.9 \\
Undecided & 25 & 9.9 \\
Disagree & 16 & 6.3 \\
Strongly disagree & 19 & 7.5 \\
Total & $\mathbf{2 5 2}$ & $\mathbf{1 0 0}$ \\
\hline
\end{tabular}

Table 9 shows that out of 252 respondents surveyed, 99 or 39.3 percent strongly agree that development of tourism is influenced by marketing and public relations strategies, 93 or 36.9 percent agree, 25 or 9.9 percent were undecided, 16 or 6.3 percent disagree while 19 or 7.5 percent strongly disagree.

\section{Test of Hypotheses}

Three hypotheses were tested using multiple regression models in SPSS version 20. The single dependent variable (tourism development) was regressed against the three independent variables (documentaries/film shows, awards/ceremonies and facility visits/sponsorship).

Table 10.

\begin{tabular}{lrr}
\hline Descriptive Statistics & \\
\hline \multicolumn{3}{l}{ Mean Std. DeviationN } \\
\hline Dourism Development & 3.93651 .20256 & 252 \\
Awumentaries and films & 4.12301 .10628 & 252 \\
Awards and ceremonies & 4.02781 .10198 & 252 \\
Facilities visist and sponsorship4.09131.11295 & 252 \\
\hline
\end{tabular}

Table 11.

\begin{tabular}{|c|c|c|c|c|c|}
\hline \multicolumn{6}{|l|}{$\overline{\text { Correlations }}$} \\
\hline & & $\begin{array}{l}\text { Tourism } \\
\text { Development }\end{array}$ & $\begin{array}{l}\text { Documentaries } \\
\text { and films }\end{array}$ & $\begin{array}{l}\text { Awards and } \\
\text { ceremonies }\end{array}$ & $\begin{array}{l}\text { Facilities visit and } \\
\text { sponsorship }\end{array}$ \\
\hline \multirow{4}{*}{ Pearson Correlation } & $\begin{array}{l}\text { Tourism } \\
\text { Development }\end{array}$ & 1.000 & .946 & .972 & .954 \\
\hline & $\begin{array}{l}\text { Documentaries and } \\
\text { films }\end{array}$ & .946 & 1.000 & .961 & .987 \\
\hline & $\begin{array}{l}\text { Awards and } \\
\text { ceremonies }\end{array}$ & .972 & .961 & 1.000 & .972 \\
\hline & $\begin{array}{l}\text { Facility visits and } \\
\text { sponsorship }\end{array}$ & .954 & .987 & .972 & 1.000 \\
\hline \multirow{4}{*}{ Sig. (1-tailed) } & $\begin{array}{l}\text { Tourism } \\
\text { Development }\end{array}$ & & .000 & .000 & .000 \\
\hline & $\begin{array}{l}\text { Documentaries and } \\
\text { films }\end{array}$ & .000 & $\cdot$ & .000 & .000 \\
\hline & $\begin{array}{l}\text { Awards and } \\
\text { ceremonies }\end{array}$ & .000 & .000 & . & .000 \\
\hline & $\begin{array}{l}\text { Facility visits and } \\
\text { sponsorship }\end{array}$ & .000 & .000 & .000 & - \\
\hline
\end{tabular}




\begin{tabular}{|c|c|c|c|c|c|}
\hline \multirow{4}{*}{$\mathrm{N}$} & $\begin{array}{l}\text { Tourism } \\
\text { Development }\end{array}$ & 252 & 252 & 252 & 252 \\
\hline & $\begin{array}{l}\text { Documentaries and } \\
\text { films }\end{array}$ & 252 & 252 & 252 & 252 \\
\hline & $\begin{array}{l}\text { Awards and } \\
\text { ceremonies }\end{array}$ & 252 & 252 & 252 & 252 \\
\hline & $\begin{array}{l}\text { Facility visits and } \\
\text { sponsorship }\end{array}$ & 252 & 252 & 252 & 252 \\
\hline
\end{tabular}

Table 12.

\begin{tabular}{llllll}
\hline \multicolumn{6}{l}{ Model Summary showing the relationship between the dependent and independent variables } \\
\hline Model & $\mathrm{R}$ & R Square & Adjusted R Square & Std. Error & of \\
& & & & Estimate & \\
1 & $.973^{\mathrm{a}}$ & .947 & .947 & .27771 & 1.742 \\
\hline
\end{tabular}

a. Predictors: (Constant), Facility visits and sponsorship, Awards and ceremonies, Documentaries and films

b. Dependent Variable: Tourism Development

Table 13.

\begin{tabular}{|c|c|c|c|c|c|c|}
\hline \multicolumn{7}{|c|}{ ANOVA table of the independent variables ${ }^{a}$} \\
\hline Model & & Sum of Squares & df & Mean Square & $\mathrm{F}$ & Sig. \\
\hline \multirow{3}{*}{1} & Regression & 343.858 & 3 & 114.619 & 1486.220 & $.000^{\mathrm{b}}$ \\
\hline & Residual & 19.126 & 248 & .077 & & \\
\hline & Total & 362.984 & 251 & & & \\
\hline
\end{tabular}

a. Dependent Variable: Tourism Development

b. Predictors: (Constant), Facility visits and sponsorship, Awards and ceremonies, Documentaries and films

Table 14.

\begin{tabular}{|c|c|c|c|c|c|c|}
\hline \multicolumn{7}{|c|}{ Coefficients $^{\mathrm{a}}$} \\
\hline \multirow{2}{*}{\multicolumn{2}{|c|}{ Model }} & \multicolumn{2}{|c|}{ Unstandardized Coefficients } & \multirow{2}{*}{$\begin{array}{l}\text { Standardized } \\
\text { Coefficients } \\
\text { Beta } \\
\end{array}$} & \multirow[t]{2}{*}{$\mathrm{t}$} & \multirow[t]{2}{*}{ Sig. } \\
\hline & & $\mathrm{B}$ & Std. Error & & & \\
\hline & (Constant) & -.376 & .068 & & -5.537 & .000 \\
\hline & Documentaries and films & .150 & .101 & .138 & 1.497 & .136 \\
\hline \multirow[t]{2}{*}{1} & Awards and ceremonies & .896 & .068 & .821 & 13.124 & .000 \\
\hline & $\begin{array}{ll}\text { Facility } & \text { visits } \\
\text { sponsorship } & \\
\end{array}$ & .020 & .118 & .019 & .172 & .864 \\
\hline
\end{tabular}

a. Dependent Variable: Tourism Development

Table 15.

\begin{tabular}{llllll}
\hline \multicolumn{7}{l}{ Residuals Statistics } & \\
\hline & Minimum & Maximum & Mean & Std. Deviation & $\mathrm{N}$ \\
\hline Predicted Value & .6909 & 4.9580 & 3.9365 & 1.17045 & 252 \\
Std. Predicted Value & -2.773 & .873 & .000 & 1.000 & 252 \\
Standard Error of Predicted Value.018 & .101 & .030 & .018 & 252 \\
Adjusted Predicted Value & .6794 & 4.9650 & 3.9368 & 1.17067 & 252 \\
Residual & -.95803 & .30908 & .00000 & .27604 & 252 \\
Std. Residual & -3.450 & 1.113 & .000 & .994 & 252 \\
Stud. Residual & -3.462 & 1.133 & -.001 & 1.001 & 252 \\
Deleted Residual & -.96501 & .32058 & -.00030 & .27999 & 252 \\
Stud. Deleted Residual & -3.542 & 1.134 & -.006 & 1.016 & 252 \\
Mahal. Distance & .101 & 31.964 & 2.988 & 6.221 & 252 \\
\hline
\end{tabular}




\begin{tabular}{llllll}
\hline Cook's Distance & .000 & .122 & .004 & .011 & 252 \\
Centered Leverage Value & .000 & .127 & .012 & .025 & 252 \\
\hline
\end{tabular}

a. Dependent Variable: Tourism Development

Source: SPSS Version 20 output of multiple regression

Interpretation: The $\mathrm{R}^{2}$ value (0.947) shows a significant positive relationship between tourism development and public relations strategies. Also, the $\mathrm{F}$ value (148) and $\mathrm{p}$ value $(0.000)$ which are greater than $\mathrm{f}$ critical value at 0.05 level of significance (6.39) and less than alpha (0.05) respectively are positive signs of relationship. However, the coefficients table shows that documentaries and film shows $(\mathrm{t}=1.494 ; \mathrm{p}=0.136)$ is Not a significant predictor of tourism development. Also, facilities visits and sponsorship $(\mathrm{t}=0.172 ; \mathrm{p}=0.864)$ in Not a significant predictor of tourism development. This is because their $\mathrm{p}$-values are greater than alpha (0.05) and their t-values less than table value of $\mathrm{t}$. However, the table shows that awards and ceremonies $(\mathrm{t}=13.124 ; \mathrm{p}=0.000)$ is a significant predictor of tourism development since the $\mathrm{p}$-value is less than alpha and the $\mathrm{t}$-value greater than $\mathrm{t}$-critical.

Decision: Given the above outcomes, we therefore reject the alternate hypotheses one and three and accept their nulls, which implies that documentaries and film shows, facility visits and sponsorship do not significantly predict tourism development in Nigeria. On the other hand, the null hypothesis two is rejected while the alternate is accepted, thus, awards and ceremonies significantly predict tourism development in Nigeria.

\section{Discussion of Findings}

Findings revealed from the analysis of data obtained and test of hypotheses formulated in the study included that; documentaries and film shows have significant effect on tourism development in Nigeria. The implication of this finding is that documentaries and film shows are dashboard that direct the wind of development campaign of the industry in the country. This is in consonance with the findings of Nnabuko (2007), Etuk, (2003) who observed that public relations strategies and tactics define direction for organization operations in order to cope with the sophisticated and changing taste of customers in a constantly changing business environment as to attain the stated desired goals.

Data that were collected and analyzed revealed the finding that awards and ceremonies have significant effect on the development of tourism in Nigeria. The finding implies that awards and ceremonies can enhance the building and marketing of destination brand image appropriately to the target markets. This is supportive of the finding by Chukwu (2016) with the submission that public relations techniques assist in the projection and promotion of corporate brands in both domestic and international markets.

Analyses of data also revealed the finding that facility visits and sponsorship of discussion groups not only promotes tourism development but as well add value to the industry at large. This is in supportive with the findings of Trojan (2005), that public relations strategies are useful in tracking brand or destination image and handling of activities at peak levels.

\section{Conclusion}

The study on public relations strategies on the development of tourism in Nigeria is strategic and crucial to repositioning of destinations' image, good will and reputation. Public relations strategies are viable techniques and lubricants that are very essential to the revitalization of the industry in Nigeria. This will incite new tourists and retain loyal ones. Therefore, destination management organizations must view public relations strategies as the veins and arteries that carry blood from the "heart" of tourism and supply blood fluids of communication to the entire system in a give and take mechanism based on mutual understanding to harmonize destinations and tourists' interest and close credibility gap.

\section{Recommendations}

The following recommendations were made based on the findings of the study. That:

1. The governments at all levels should plan or develop a tourism philosophy that will lay the foundation of Nigeria tourism products as this will guide the nation on the type of tourism that will be consistent with our national values, aspirations and ideologies.

2. Governments at all levels and her relevant tourism agencies should involve relevant stakeholders especially public relations and marketing professionals with their skills, experience, knowledge in brand image building and contact with the destination and environment in formulation of objectives and strategies for the industry. 
3. Destination management organizations should improve and intensify efforts on effective and efficient use of documentaries and film shows, awards and ceremonies as well as facility visits and sponsorship of discussion groups to accurately position the sector as a veritable economic catalyst that can be use to stimulate investment for economic growth and development in Nigeria.

\section{References}

Amagwu, I. F. (2009). Developing marketing strategies and plans for the banking industry in Nigeria in Biannual. Journal of Nigerian Institute of Public Relations, 6(1\&2).

Benson-Eluwa, V. (1999). Public relations: A practical approach, Enugu: Virgin creation.

Bhatia, A. K. (2006). Tourism development: Principles and practice, New Delhi: sterling publishers.

Bogan, E. (2016). Communication and promotion policy in tourism marketing. International Journal of Academic Research in Environment and Geography, 1(1).

Center, A. H., Jackson, P., Smith, S., \& Stanberry, F. R. (2008). Public relations practices: Managerial case studies and problems, New Delhi: PHI Learning Private Limited.

Chukwu, I. C. (2016). Strategic media relations and reputation management: $21^{\text {st }}$ century media relations and information management techniques, Lagos: Dynotech Nigeria Ltd.

Deboski, M. (2013). Marketing communication as a tool of building tourism destination competitiveness. Selected Issues Management, 17(1).

Ebitu, E. T. (2012). Marketing communications: An integrated approach, Calabar: University of calabar press.

Esu, B. B. (2015). The relevance of marketing in Nigerian tourism development: A paper presented at national institute of marketing of Nigeria during marketing students Annual Conference held at Pius Anyim Hall, Michael Okpara University of Agriculture, Umudike, May, 6-7.

Etuk, E. J. (2003). Marketing management dyadic interface: Environmental, strategic and research imparatives for national self-reliance and development, Calabar: University of Calabar press.

Federal Government of Nigeria Budget Proposal. (2013-2015). Retrieved from http://budget.office.Gov.ng

Fill, C (2009). Marketing communications: Interactivity, communities and consent, Harlow: Prentice Hall.

Hovland, T., Janis, O., \& Kelly, B. (1996). Public relations, Harlow: Pearson Education Ltd.

Jefkins, F. (2005). Public relations, Harlow: McGraw Educational.

Kotler, P., Bowen, J. T., \& Markens, J. C. (2010). Marketing for hospitality and tourism, NewYork: Pearson Education Publishers.

Neliaku, I. (2011). Public relations and information management for sustainable human development in a democratic Nigeria 2008. Public Relations Journal, 7(1)

Nnabuko, J. O. (2007). Effective organizational public relations strategic planning in Nwosu, I. E. edited public relations: Insight from Nigeria, Enugu: Ezu Book Ltd.

Nwosu, I. E. (2001). Marketing communications management and media: Principles practice and strategies, Aba: Dominican publishers.

Nwosu, I. E., \& Uffoh, V. O. (2005). Environmental publc relations management: Principles, strategies, issues and cases, Enugu: Institute for Development studies, UNEC.

Ogakwu, V. N. (2009). Mainstreaming special education programmes for sustainable development in Nigeria: The critical role of public relations. Journal of Nigerian Institute of Public Relations, $6(1 \& 2)$.

Ogunnubi, B. (2017). Boosting internally generated revenue (IGR) with tourism. The Sun Newspaper, 13(3624) 16.

Okoli, C. (2007). Event management: spotlight on tourism and hospitality. Webs media communications, owerri.

Uchechukwu, I. (2012). That the tourism industry be sustainable, viable in Cross River state, Weekend Chronicle Friday, April 20.12.

Wood, M. B. (2007). Essential guide to marketing planning, London: Prentice Hill. 


\section{Copyrights}

Copyright for this article is retained by the author(s), with first publication rights granted to the journal.

This is an open-access article distributed under the terms and conditions of the Creative Commons Attribution license (http://creativecommons.org/licenses/by/4.0/). 